Origins and evolution of elementary social studies in Australia, 1930-1970

Lindsay J Parry

The Social Studies; Mar/Apr 1998; 89, 2; Academic Research Library

pg. 77

\title{
Origins and Evolution of Elementary Social Studies in Australia, 1930-1970
}

\author{
LINDSAY J. PARRY
}

$\mathbf{S}$ ocial studies is a significant, complex, and dynamic component of formal schooling in its birthplace, the United States, and in many other societies throughout the world. Indeed, the spread of the American concept of social studies, its philosophical ideas. and its instructional practices has known no social, cultural, or political boundaries. This educational phenomenon has been linked to the pervading force of progressivism in the 1930s and 1940s (Hertzberg 1989) and to globalism and the internationalization of education, which gained momentum in the decades following the Second World War (Openshaw 1992), In recent decades, the social studies field has been perceived as an "emerging transnational profession" that is no longer "owned" by any single society and is not the "exclusive province" of Americans (Mehlinger and Tucker 1979).

The chronicle of the origins and evolution of the social studies profession represents something of a mixed picture. Social studies in the United States has been well documented by accounts

LINDSAY J. PARRY teaches social studies curriculum as a member of the Farulty of Education al Griffith University in Nathan. Australia. dealing with its origins as a professional field (Jarolimek 1981, Lybarger 1981. Sheris 1989), its major curriculum development and reform efforts (Hertzberg 1971. 1981, 1982, 1988; Mehaffy 1979; Haas 1977. 1979. 1986; Isham 1982; Isham and Mehaffy 1985; Peet 1984; Ravitch 1985, 1987; Jenness 1990), and the historical legacy of individuals and ideas (Barr, Barth, and Shermis 1977: Nelson 1990; Fenton 1991; Correia and Watkins 1991; Whelan 1991, 1994; Massialas 1992: Dow 1992: Rossi 1992; Thevenet 1994: Correia 1994; and Nelson 1994). Unfortunately, much less is known about the widespread adoption of social studies by societies other than the United States and the transplanting of ideas and practices across educational boundaries, particularly during periods of profound social, cultural, and political change.

The study of the adoption of social studies in other societies is needed because individual milicux and contexts, in the words of Ivor Goodson (1992, 25). "differ very substantially and our insights into school subjects and schooling have a unique significance in each particular country, at each particular time." Furthermore, such study "provides us with a window on the wider educational and political culture of a country" and enables us to unravel "precisely how this global pattern interacts and collides with more local/national cultures and structures" (Goodson 1992. 25). We need to know why social studies has been adopted in different social, cultural, and educational contexts, and its relationship to progressive education. Similarly, we need to know how particular philosophical principles and instructional practices have been taken up in different contexts and during contrasting periods of curriculum development and reform. In short. we need to explain how and why social studies has evolved into an emerging transnational profession and account for its varying manifestations in diverse social, cultural. and educational contexts.

In this article, I explore the transnational character of social studies in Australia from 1930 to 1970 and the influential and far-reaching nature of ideas and decisions made at that time. I specifically examine the origins and evolution of social studies in Australia by presenting a historical case study of the adoption of social studies ideas and practices in elementary schools in the state educational system of Queensland cone of eight states and territories of 
Australia) from 1950 to 1970 . During that time, the American concept of social studies was adopted as a single subject in the elementary school curriculum by the Department of Education in Queensland, which sought to integrate the academic disciplines of history, geography, and civics education. The "new" subject of social studies promoted the development of responsible citizenship through the transmission of historical and culturally significant knowledge and the inculcation of societal values and norms that are best described as traditional and conservative. In reconstructing this historical case study, I have paid particular attention to the centrality of context in explaining the adoption and evolution of social studies in the social, cultural, and political setting of Australia; the selection of content and instructional practices in social studies and their relationship to progressive educational assumptions; and perceptions of the impact of the subject on local educational structures and instructional practices in the classrooms of Queensland state elementary schools.

\section{Educational Policy Making and Other Contextual Influences in Australia, 1930 to 1970}

My account of the adoption of social studies in Queensland begins with a descriptive-analytic overview of educational policymaking and other contextual influences in Australia from 1930 to 1970, when the American concept of social studies began to emerge in various guises in elementary, secondary, and technical (trade) schools. This overview is based on the premise that educational policymaking and curriculum development efforts are social processes that may be understood only when they are situated within specific social, cultural, and political contexts. These contexts are characterized invariably by significant similarities and differences within, as well as across, individual societies. In this sense, I have noted significant similarities and differences in relation to the origins and evolution of social studies in both the Unit- ed States and Australia to illuminate particular developments in Queensland. This contextual backdrop allows for a broadened perspective, enhanced insight, and reduced parochialism.

Without a doubt, the period from 1930 to 1970 stands out as an extraordinarily significant era in Australia's social and cultural history. During that era, Australian society was affected profoundly by social, cultural, and political forces that have shaped its national identity and public policy to the present. At the beginning of the era, Australia was faced with two international crises that compelled Australians to reexamine the foundations of social life and public policy. The first crisis was the world slump of 1929, which resulted some four years later in nearly one-third of Australian breadwinners' being unemployed at the height of the economic depression. The second crisis was the Second World War from 1939 to 1945, which saw Australian troops involved in military campaigns in Africa, Asia, Europe, and the Pacific. The end of the era is marked by the adoption of "multiculturalism" in 1973, a bipartisan approach to ethnic and cultural diversity that literally ushered in a whole new age for Australian society. Indeed, multiculturalism was adopted as "a state strategy for managing difference" (De Lepervanche 1980, 24) and led to the ethnicization and politicization of the immigrant groups that had increased in number and diversity after the Second World War. In fact, the composition of Australian society has been transformed with the arrival of immigrants from more than one hundred different ethnic and cultural groups.

Ethnic and cultural diversity in Australian society has produced many contradictions and paradoxes. Whereas the population has become ethnically and culturally diverse, Australia's national identity and sociopolitical institutions have remained largely monocultural, rooted in British history and tradition (Jamrozik, Boland, and Urquhart 1995). Australia remains an Englishspeaking democracy whose constitutional provisions, governmental structures, and sociopolitical institutions have not been transformed to reflect a multicultural population. Australia has been reluctant to leave the British Commonwealth and reinvent its national identity and sociopolitical institutions, as evidenced by the fact that republicanism and constitutional reform are only now being debated as distinct possibilities for Australia by the turn of the century. Indeed. a certain unease still exists about how Australia's recent ethnic and cultural diversity ought to be encapsulated in its national identity and translated into public policy.

Australia is governed federally but has created a public educational system that resides constitutionally in individual states. Major educational differences exist among the states, and conflicts are frequent over state-federal rights and responsibilities at all levels of educational policymaking and curriculum development. In the postwar decades. the character of Australian schooling was shaped by nineteenthcentury legislation that sought to provide equality of opportunity for all students, irrespective of their geographic or socioeconomic position (McKenzie 1995). Centralized administrative systems were devised to control school resources, staffing, and curricular uniformity throughout each state. By the early 1970s, the centralized state educational systems struggled to serve a student population that was becoming more diverse in its educational expectations and ethnic and cultural backgrounds. The role of the federal government at all levels of education also had grown noticeably, particularly in relation to centralization and decentralization, educational accountability, and the development of national curriculum frameworks. Much uncertainty remains, however, about the appropriate balance of state and national responsibility for schooling.

\section{Adoption of Social Studies and American Influences}

The adoption of social studies by Australian educational systems from 1930 to 1950 is comparatively a contemporary educational phenomenon. In 
fact, social studies only emerged as a curriculum entity in Australia some two to three decades after receiving official recognition and widespread acceptance in the school curriculum of the United States following the First World War and the release of the 1916 Report (Shermis 1989). In Australia, social studies grew out of the emerging influence of educators and ideas from the United States and increasing local dissatisfaction with the traditional and conservative academic curriculum of history, geography, and civics and their associated instructional practices that emphasized passive and independent learning.

The American influence on the adoption and evolution of social studies in Australian educational systems cannot be overstated. This is hardly surprising given the growing American influence upon many facets of national and civic life in Australia. an outcome of the expansive predominance of the United States in the Asian and Pacific regions and the export of American social. cultural, and political ideals throughout this century (Cremin 1988). Multinational corporations based in the United States were influencing the Australian economy and society, especially with their mining and pastoral interests in Queensland. and persuasive infiltration of all aspects of the mass media. It is little wonder that educators and ideas from the United States began to influence curricular provisions and instructional practices in Australian schools.

Those influences were reflected most tellingly in the international conferences of the New Education Fellowship (NEF) in 1934 and 1937, which marked the turning point for the adoption of social studies by Australian educational systems. In 1937, a series of NEF conferences were staged at multiple sites across the country and addressed the theme, "Education for Complete Living." Those rolling conferences were planned and financed by the Australian Council for Educational Research (ACER), which had been formed some seven years earlier with philanthropic funding from the Carnegie Corporation. In all. over three hundred papers were presented at seven different metropolitan venues across Australia.

At the conferences, prominent educators from the United States questioned the capacity of the traditional academic curriculum to deal effectively with the individuality of the child, emerging progressive educational assumptions, and socially relevant issues. A leading progressive educator, Harold Rugg (a professor of education at Teachers College, Columbia University), advocated the "fusion" or "correlation" of the separate disciplines of history, geography, and civics into social studies and the adoption of progressive teaching approaches that emphasized student-directed learning. The articulation of those and other progressive ideals at the 1934 and 1937 NEF conferences provided much needed educational responses to the economic and social upheavals precipitated by the depression and helped to reshape curricula in Australia. It remained for state educational systems and individual educators to translate those new opportunities into school and classroom realities over the next two decades.

By 1938, the first documented classes in social studies in Australia were being held at Preston Technical School in Victoria (Edwards 1987). Classes in social studies were held for those technical students who were labeled underachievers, and the status of the subject remained low. Despite its tentative beginnings. the unprecedented turmoil of the Second World War and its aftermath provided a further catalyst for the growth and acceptance of progressive educational ideals at various levels in Australian education. "In one sense," observed Trethewey (1968, 274), "the War delayed curriculum revision, but it also provided a time for the spread of new ideas, and from it came support for the imminent changes." An emerging conviction that gained momentum in the postwar years was that education "should be an instrument for the improvement of society" (Trethewey 1968, 274). "If men [sic]," continued Trethewey (1968, 274), "were to live together in harmony, and if human freedoms were to be safe-guarded, the edu- cation of the young should be directed quite deliberately to these ends." Following the success of the NEF conferences and early experimentation at Preston Technical College, social studies was introduced progressively into most Australian technical schools in the early 1940s, into secondary schools in the late 1940s, and into elementary schools in the early 1950s (Barcan 1950, 1971). By the early 1950s, the shift from a traditional and conservative academic curriculum monopolized by history, geography, and civics to a humanistic, progressive, generalist education under the banner of social studies had emerged as a new educational imperative in Australia.

As happened in the United States some twenty to thirty years earlier, the increasing popularity of social studies also reflected the acceptance of progressive educational assumptions that, along with other concerns, were critical of the instructional practices employed in history and geography teaching. That dissatisfaction led ultimately to the widespread adoption of social studies in favor of the teaching of individual subjects of geography and history in Australian elementary and lower secondary schools along with changing attitudes toward discipline, studentdirected learning, and examination procedures (Barcan 1950, 87). Interestingly, social studies has never really challenged the supremacy of history and geography in the curriculum of senior secondary schools (Barcan 1971, 16). Social studies has been seen as providing essential learning for younger pupils but gives way to an academic curriculum, traditionally geography and history, at a certain point in the secondary school (Shermis 1992, 94). In contrast, social studies sought to provide all pupils, and especially those of lower ability, with an interesting, contemporary, and relevant social-civic education (Barcan 1971, 18). For as Trethewey $(1968,275)$ lamented, "History had died as a subject in order to give 'new life' to studies in the elementary school which, it was thought, served the purposes of education more effectively but mainly as a subject for 
lower ability pupils." Above all, social studies was expected to prepare pupils for the practical problems of living in a rapidly changing democracy.

It is significant that although all the other Australian states had begun to embrace the ideals of social studies from the late 1930s, there was little noticeable impact in Queensland until the early 1950s. Social studies was director-general of education) in his Annual Departmental Report for 1950. "has been engaged for some time in overhauling the curriculum" and "believes that, even under the old curriculum and methods. the children should be in good health-physically, mentally, and morally" (Department of Education 1950,37 ). The curriculum overhaul that was undertaken from 1947 to

\section{In the Department of Education's 1952 syllabus, social studies was featured prominently and provided the foundation for a modern and relevant education for all future citizens. Its central goal was the development of children for their future role in the "work of life."}

first introduced into elementary schools in 1952 and only appeared in lower secondary schools in 1965, following a national seminar. "The Teaching of the Social Sciences at the Secondary Level," that was held in Burwood (Melbourne) under the auspices of the Australian National Advisory Committee for UNESCO. The delayed acceptance of social studies by educational authorities in Queensland was due to entrenched beliefs in the value of a formal academic curriculum and the capacity of history and geography, as taught in elementary classrooms, to prepare pupils for more structured, complex, and demanding disciplinary studies in the secondary school.

As significant is the fact that the emergence of social studies in Queensland elementary schools was not part of a broader state curriculum reform movement and attracted little fanfare in departmental policy documents and communiqués to schools. Indeed. social studies was seen by departmental curriculum workers as providing further support to an already "healthy" curriculum that was outlined in detail in The Syllabus or Course of Instruction in Priman and Intermediate Schools (1930). "A team of experts," wrote L. D. Edwards (then the
1952 resulted only in the modification and adjustment of the goals, content, and methods of the preceding syllabus, as in the words of Edwards, "no fault has been found with the 1930 statement of educational objectives" (Department of Education 1950, 37). "Education," Edwards continued, "does not lend itself to really radical change. Changes should be evolutionary rather than revolutionary. They should not be merely spectacular or fanciful innovations, but should be designed to meet some real social need" (Department of Education 1950, 37).

In advocating gradual curriculum change. Edwards sought to reassert implicitly the value of child-centered and progressive educational assumptions popularized in Australia after the depression and their continuing relevance for elementary schooling following the equally turbulent years of the Second World War and its aftermath. His assertion represented a continuation of the educational ideals articulated in the 1930 syllabus that espoused the ideology of "social efficiency," an educational version of progressivism that was critical of school subjects which had no practical value or offered little promise of immediate social betterment. It was an ideology that was to be articulated with great clarity in the overhauled edition of The Syllabus or Course of Instruction in Primary and Intermediate Schools (1952), arguably the single most important statement for social studies throughout the 1950s and 1960s. It read as follows:

It is generally agreed that the Elementary School...should develop a sound mind in a sound body, to arouse a living interest in the ideals and achievements of mankind (sic); to give the pupils some familiarity with literature and history particularly those of their own country; to give some power over language as an instrument of thought and expression; to give a taste for good reading and thoughtful study: to develop intelligence, habits of observation. and clear reasoning; or. summarising. to make the best use of the school years in assisting the pupils to tit themselves, intellectually and practically, for the work of life. (Department of Education 1952, 6)

Social studies featured prominently in that philosophical statement by providing the foundation for a modern and relevant education for all future citizens. It was to take as its central goal the development of the "child" and to play a significant educational role in the preparation for "the work of life" and in directly strengthening national and economic development. "The child rather than the subject," stressed the syllabus, "is the first and constant concern of the teacher" (Department of Education 1952, 1). "Emphasis should be placed on the interest. needs, activities, and experiences of the pupils and not on the subject matter which is a means to an end, not an end in itself." In reinforcing the emphasis on the child rather than the subject, the 1952 syllabus adopted three interrelated educational imperatives: a concern for the preparation of the child for life: a concern for the child through the "fusion" and "correlation" of the academic disciplines; a concern for the child through the adoption of progressive instructional practices. Each is discussed below.

\section{Preparation of the Child for Life}

A concern for the preparation of "the child for life as an effective citizen of the community" (Department of Educa- 
tion 1952,11 was accepted as the proper goal of the social studies curriculum in the 1950s and 1960s. The goal of "effective citizenship" was to be achieved through the transmission of selected aspects of cultural heritage and the inculcation of beliefs and behaviors considered essential in society. Pupils were to participate in learning activities that related to the actual experiences of the child and those likely to be encountered throughout life. The goal, according to the 1952 syllabus, "implies that teaching will not be directed towards producing individuals sufficiently informed, but will be directed to the building of desirable social habits and attitudes. Children should be led to see in what way our democratic practices are desirable and trained to act with that intelligent understanding so vital to democratic living" (Department of Education 1952. 1). Curriculum workers also looked to the fusion and correlation of the academic disciplines as a means of achieving this goal.

\section{The "Fusion" and "Correlation" of Academic Disciplines}

The intellectual foundation of the social studies curriculum also was characterized by the fusion and correlation of the academic disciplines of history, geography, and civics and thereby represented a departure "from the rigid, convenient but artificial subject approach in formal education" (Department of Education 1952, 1). Not surprisingly, the discipline of history was endorsed as the central and synthesizing discipline within the social studies curriculum and reflected a continuation of the educational ideas of the 1930 syllabus. The formal study of history was to focus on the transmission of selected aspects of cultural heritage and be presented as a "story well told." History. according to the 1930 syllabus, "is the formal story of the growth of a nation. It may be regarded as a picture or pageant of events which resulted from the lives and achievements of the men and women who lived before our time" (Department of Public Instruction $1930,6)$. Pupils were "to be told of the manner in which people lived, of characters and deeds, of their adventures and discoveries. Generally, the aim in history-teaching should be to so represent the past as to lead children to appreciate the present" (Department of Public Instruction 1930.6).

That conception of history was endorsed further in the 1952 syllabus as teachers were to recount stories of the achievements of outstanding people. such as Columbus, Joan of Arc, Vasco de Gama, Grace Darling. Magellan. Florence Nightingale, and William Tell. and were to retrace the steps of Australian explorers, such as Cook, Flinders, Bass, and Kennedy. Consequently. European and Australian history was "to be taught in such a way as to show a connected story of progressive development" (Department of Public Instruction 1930,6). According to Quinn, the story of progressive development was constructed more as "a dissertation in the glorification of white achievements and as a means of promoting nationalist sentiment" (Quinn 1992, i). Instructional strategies that endorsed progressive educational assumptions from the 1930s and 1940 s also were employed to prepare pupils for their rights and responsibilities as effective citizens.

\section{Adoption of Progressive \\ Instructional Practices}

The social studies curriculum was to be child-centered in the sense that selforiginated, self-imposed, and selfdirected learning based on progressive educational assumptions was advocated in the 1952 syllabus. In particular, the syllabus favored the use of projects and other activity methods over the rote learning and memorization of accepted historical facts and opinions. According to the 1952 syllabus (Department of Education 1952, 1), "social studies implies more than a correlation of subjects. It implies also a new approach." The new, child-centered approach presented "a challenge to the teacher upon whom devolves the real responsibility of making this section of the syllabus new. The teacher must devise methods of instruction. decide upon the depth of treatment of matter, and arrange experiences" (Department of Education 1952. 1). The continuing prominence of these positivist educational ideals in the statement of intentions and goals of elementary education, and more specifically in the syllabus for the emerging curriculum area of social studies, was to shape state elementary schooling in Queensland throughout the 1950s and 1960s.

\section{Perceptions of Social Studies in Elementary Schools, 1950 to 1970}

In this section. I will present individual perceptions of the actual social studies curriculum implemented in state elementary classrooms of the $1950 \mathrm{~s}$ and 1960s. The perceptions are drawn from written and oral testimonies of educators who observed classrooms at that time or were involved in their operation on a daily basis. As we shall see, their testimonies suggest that the translation of childcentered and progressive instructional practices advocated in philosophical statements, syllabus documents, and related curriculum materials in social studies was rarely actualized in elementary classrooms of the 1950s and 1960s.

The implementation of the social studies curriculum became problematic in part because of structural inadequacies and internal inconsistencies in the design and presentation of the 1952 syllabus. In its preamble, the syllabus advocated the intellectual development of the child. rather than the acquisition of subject matter. Yet the curriculum content to be covered at each grade level was specified in detail, with important dates to be learned by pupils placed in brackets in the text. Few suggestions, if any, were made about instructional practices. Texts and supporting curriculum materials were factually oriented and became the focus of classroom instruction. One school principal, in noting such shortcomings, described the syllabus best by calling it "just a bare-bones sort of thing, pitiful in lots of ways" (Graham 1993).

More significant was the fact that the new subject area of social studies faced 
an identity crisis and open rejection by many principals and teachers in elementary schools and classrooms. Social studies was criticized for making the elementary school curriculum less academic, more utilitarian, less subjectcentered, and more closely related to the interests and experiences of pupils (Akhurst 1978). Even the newly appointed director of primary education (Queensland) in early 1969 commented, "I just had to accept the fact that the Department of Education was hell bent on social studies. It was the fashion" (Howells 1993).

These criticisms of social studies and those of others were duly noted by a visiting American scholar, R. Freeman Butts, in the mid-1950s. Social studies had been taught for two years in Queensland elementary schools when Butts (a professor of education at Teachers College, Columbia University) undertook a Fulbright research program to identify and interpret assumptions underlying Australian education in 1954. In the classic Assumptions Underlying Australian Education, Butts (1955) was one of the first educators from the United States to provide an extensive commentary on Australian educational systems. Sympathetic to the ideals and forms of progressive education, Butts found Australian schooling lacking in its major characteristics. He observed little evidence of studentcentered learning based on individual needs, curricula based on social problems and group activities, or flexibility and individual initiative in teachinglearning situations. Instead, Butts described Australian education as strikingly uniform, traditional, formal, and rigid. Schools were perceived as being elitist institutions that catered exclusively to university-bound students. Schools transmitted mainly academic knowledge that was poorly focused on Australian society and employed drill and teacher-centered instruction.

Most important, Butts observed a significant gap between the prescribed and enacted curriculum in elementary schools and was concerned deeply about the absence both of relevant instruction based on progressive educa- tional thinking and of specific instructional practices conducive to the development of good citizens. "Despite the statements in the printed elementary syllabi," observed Butts $(1955,60)$, "the goal of education in practice was not the cultivation of interests, not the development of desirable attitudes, not the formation of sound judgments, not personal or social adjustment, not the creation of good citizens. It was the efficient expression of knowledge. This is what it is assumed the schools should be about. The elementary schools of Australia," concluded Butts $(1955,61)$. "assume that the claims of the learners and the claims of society are less important than the claims of knowledge." The teaching of social studies in state elementary classrooms was teacher-centered, emphasized rote learning, and used texts as the main focus of classroom instruction. Skills were restricted largely to basic map making and the presentation of factually based historical and geographical knowledge, with little attempt at correlation or integration.

However, the use of activity and project methods in which students undertook research activities to investigate a topic, issue, or theme was noted as a major concession to the philosophical and pedagogical approaches of progressive education espoused in the United States in the 1920s by John Dewey and William Kilpatrick respectively. Nevertheless, the adoption of social studies and its progressive instructional practices generally was viewed with suspicion by many educators. Progressive instructional practices were seen as lacking academic rigor, eroding the place of the traditional disciplines of history and geography within the curriculum, and leading ultimately to the detriment of elementary education. As Butts (1955, 46) succinctly acknowledged, "Social studies is looked upon as diffuse, vague, a hodge-podge of nothing in particular. It is assumed that history and geography will give systematic knowledge and information, whereas social studies will 'play around' with activities and projects that do not contain rigorous intellectual content."
In his comprehensive and critical review, Butts challenged the assumptions underpinning Australian education and looked forward to a time when its schools would be much different. If Butts had been able to retrace his steps two decades later in 1974, he would have discovered that a new set of educational assumptions was rising to prominence in Australia. The emerging educational assumptions represented a further shift from a traditional academic curriculum to a generalist curriculum based on the principles of humanistic progressivism, which was intended to meet the needs of all students, with greater concern being shown toward child development and those skills involved in the cognitive and affective domains. In capturing the need for educational reform in the early 1970 s, one elementary school principal recounted the negative impact of a school inspector and his testing of social studies knowledge in the classroom of a young, probationary teacher:

1 remember an old inspector once coming into my school and gloating about a young teacher he had put through on a probation test. At that particular time, grade 5 had the three continents to do: Atrica, South America, and Australia in the one year. He sat at the back of the room and said, "When I clap my hands, you change questions from one continent to another." So, there probably was a need for some sort of change. I think everyone realised that. (Graham 1993)

That change was to come in the form of progressive educational thinking associated with the cognitive and inductive learning approaches of Hilda Taba and the "expanding environments" curriculum popularized by Paul R. Hanna in the United States. Throughout the 1970s and 1980s, those educators and their ideas began to influence elementary social studies and arguably revolutionized the nature, purpose, and instructional practices of the curriculum area in Queensland schools and classrooms.

\section{Conclusion}

The adoption of the American concept of social studies by elementary schools within Queensland and other 
Australian states is indicative of its widespread acceptance by societies other than the United States. At the very least, the historical case study reaffirms the importance and centrality of context in explaining the adoption of social studies within individual societies. its relationship to progressive education, and the perceptions of its impact on localized educational structures and instructional practices. In Australia, social studies was introduced and consolidated during two turbulent historical eras in the expectation that it would contribute to the reconstruction of society following the social upheavals of the depression and the Second World War.

In essence, the social studies curriculum adopted in Queensland elementary schools in the 1950 s and 1960 s was characterized by aspects of the "citizenship transmission tradition" identified by Barr, Barth, and Shermis (1977). That tradition of social studies sought to transmit selected aspects of cultural heritage to pupils and convey "a conception both of an ideal society and of an ideal citizenship" (Barr, Barth, and Shermis 1977, 61). "For those transmitting a clear view of citizenship," argued Barr, Barth, and Shermis, "mainstream values tend to be equated with acceptance and internalization of certain norms, beliefs and values, obedience and laws, and participation in approved activities."

In retrospect, the actual implementation of the social studies curriculum in the 1950s and 1960s may have led to the uncritical acceptance of transmitted cultural knowledge without educating students for citizenship. For as Shermis (1992) cautioned about this particular notion of citizenship education.

From their infancy, children are committed to a model of an ideal citizen and are provided models which depict the deeds which are regarded as having formed or perpetuated the society. Thus, military heroes, outstanding elected officials, explorers, inventors and the like are held up as models ... young children are persistently but covertly taught what is important and what is not, what is good and what is bad, what one should esteem and what one must avoid. . . Textbooks are also slanted as authors and publishers select material on the basis not of what has been discovered by scholars in the field but rather on the basis of what the culture wishes them to believe ... teachers tend to transmit what they perceive to be the dominant. agreed-upon values of the culture ... students may grow to adulthood without once recognizing that much of what they have learned is untrue, simplistic, one-sided and biased. What learning in this fashion does is $t o$ make certain that future citizenry do not perceive the inconsistencies, conflicts and inequities of their society. It also blinds people to an objective examination of the real world. (97-98)

That may well have been the case in Queensland in the 1950s and 1960s with the endorsement of responsible and effective citizenship as the proper goal of the social studies curriculum. It was a goal that sought to inculcate in children "a conception both of an ideal society and of an ideal citizenship" (Barr, Barth, and Shermis 1977, 61).

The endorsement of responsible and effective citizenship was to become problematic in schools. The progressive pedagogical revolution that took place in philosophical statements and syllabuses was rarely translated into the instructional practices and related curriculum materials used in Queensland schools and classrooms. Indeed, the persuasive thinking of the progressive education movement popularized in Australia throughout the 1930s and 1940s was unable to displace existing instructional practices that were deeply embedded in the elementary classrooms of the 1950s and 1960s and that had been long associated with the traditional and conservative academic curriculum of history, geography, and civics. Those classroom practices emphasized teacher-directed instruction, the teaching and learning of factual information, and testing through formal and factually based examinations. In capturing the need for profound educational change in Queensland as in other states at that time, Butts $(1955,79)$ offered the perceptive and controversial remark, "I would say that Australia needs a great educational revival." It was a sentiment that was to resonate throughout the 1970s and 1980s as a new generation of curriculum workers emerged to continue the transplanting of social studies within a dramatically changing Australian society. Their story has yet to be told.

\section{REFERENCES}

Akhurst, J. M. 1978. The decline and fall of social studies in N.S.W. ACES Revien 5(2): $11-3$.

Barcan, A. 1950. The trend to social studies. The Australian Quarterly (June) 79-93.

- 1971. Social science, history and the new curriculum. Sydney: Hick Smith and Sons.

Barr, R. D.. J. L. Barth, and S. S. Shermis. 1977. Defining the social studies. Washington, D.C.: National Council for the Social Studies.

Butts, R. F. 1955. Assumptions underlying Australian education. Melbourne: Australian Council for Educational Research.

Correia, S. T. November 1994. Old masters: Thomas Jesse Jones. Paper presented at the 74th Annual Conference of the National Council for Social Studies, Phoenix.

Correia, S. T., and W. H. Watkins. April 1991. Thomas Jesse Jones: A portrait. In The society for the study of curriculum history: Meetings and papers 1977-1991, edited by E. C. Short, 251-81. Educational Resources Information Center (ERIC).

Cremin, L. A. 1988. American education: The metropolitan experience, 18761980. New York: Harper and Row.

De Lepervanche. M. 1980. From race to ethnicity. Australian and New Zealand. Joumal of Sociology 16: 24-37.

Department of Public Instruction, Queensland. 1930. The syllabus or course of instruction in primary and intermediate schools. Brisbane: Government Printer.

Department of Education, Queensland. 1950. Annual departmental report. Brisbane: Government Printer.

- 1952. The syllabus or course of instruction in priman and intermediate schools. Brisbane: Government Printer.

Dow. P. B. 1992. Past as prologue: The legacy of Sputnik. The Social Studies 83(4): 164-71.

Edwards, K. J. 1987. Sorial studies in Victorian technical schools: 1938-1974. Unpublished MEd thesis, University of Melbourne.

Fenton. E. 1991. Reflections on the "new social studies." The Social Studies 82(3): $84-90$.

Goodson. I. 1992. Studying school subjects. Curriculum Perspectives 12(1): 23-6.

Haas, J. D. 1977. The era of the new social studies. Boulder: Eric Clearinghouse for Social Studies/Social Science Education 
Consortium.

1979. Social studies: Where have we been? Where are we going? The Social Studies $70(4): 147-54$.

1986. Is social studies impervious to change? The Social Studies 77(2): $61-65$.

Hertzberg, Hazel W. 1971. Historical parallels for the sivies and selenties: Primary sources and core curriculum revisited Boulder: ERIC Clearinghouse for Social Studies/Social Science Education Consortium.

- - 1981. Social studies reform 1880-1980. Boulder: Social Studies Education Consortium.

1982. Social studies reform: The lessons of history. In Social studies in the 1980\%: A report of project span, edited by Irving Morrissett, 2-14. Boulder: Social Science Education Consortium.

- February 1988. The 1892 committee of ten. Social Edacation 52(2): 144.45 .

1989. History and progressivism: A century of reform proposals. In Histori cal literacy: The case for history in American education, edited by P. Gagnon and The Bradley Commission on History in Schools. Boston: Houghton Mifflin.

Interview with Gerry Graham. Brisbane. Australia. 12 August 1993. Oral History Project, Griffith University.

Interview with Phil Howells. Brisbane, Australia. 11 August 1993. Oral History Project, Griffith University.

Isham, M. M. Fall 1982. Hilda Taba, 1904-1967: Pioneer in social studies curriculum and teaching. Joumal of Thought 17(3): $108-24$

Isham, M. M., and G. L. Mehaffy. 1985. Issues in social studies education: Experimentation in the social studies. Social Education 49(7): 571-74.

Jamrozik, A., C. Boland, and R. T. Urquhart. 1995. Social change and altural transformation in Australia. Cambridge: Cambridge University Press.

Jarolimek, J. 1981. The social studies: An overview. In The social studies, edited by D. H. Mehlinger and O. L. Davis. Jr Chicago: National Society for the Study of Education.

Jenness, D. 1990. Making sense of the social studies. New York: Macmillan.

Lybarger, M. B. 1981. Origins of the social studies curriculum: 1865-1916. Ph.D. diss., University of Wisconsin, Madison.

Massialas, B. G. 1992. The "new social
studies"--Retrospect and prospect. The Social Studies 83(3): 120-24.

McKenzie, P. A. 1995. Australia. In Interna tional encuclopedia of national swstems of education (2nd Ed.), edited by $\mathrm{T}$ Neville Postlehwaite. Cambridge: Cambridge University Press.

Mehaffy, G. L. 1979. Symbolic and Occupational Functions of Curriculum Discourse: An Exploration of Curriculum Theory During the Disciplines Era. Ph.D. diss., University of Texas, Austin

Mehlinger, H. D., and J. L. Tucker, (eds). 1979. Teaching social stadies in other nations. Washington, D.C.: Bulletin of the National Council for the Social Studies.

Nelson, M. R. 1990. First attempts toward a national curriculum-The committee of ten 's report on history, civil government, and political economy. In The societ for the study of curriculum history: Meetings and papers 1977-1991, edited by E. C. Short, 412-70. Educational Resources Information Center (ERIC).

- November 1994. Old masters: Lucy Maynard Salmon and early views of teaching history. Paper presented at the 74th Annual Conference of the National Council for Social Studies, Phoenix.

Openshaw, R. (ed.). 1992. New Zealand social studies: Past, present and future. Palmerston North: Dunmore Press.

Peet, T. S. 1984. A selective history of scope and sequence patterns, 1916 to 1984. Ph.D. diss.. Ohio State University.

Quinn. M. 1992. Pride and prejudice in elementary education: Images of Aborigines in the Queensland primary school curriculum, 1930-1990. The Edacational Historian's Monograph 5( I): i-iv.

Ravitch, D. 1985. From history to social studies: Dilemmas and problems. In The schools we deserve: Reflections on the educational crises of our times, edited by D. Ravitch. New York: Basic Books.

1987. Tot sociology or what happened to history in the grade schools. American Scholar 56(4): 343-54

Rossi, J. A. 1992. Uniformity, diversity, and the "new social studies." The Social Studies 83(1): 41-5.

Shermis, S. S. 1989. World War 1-Catalyst for the creation of the social studies. The Social Studies 80(1): 11-5.

1992. Social studies in New Zealand and in the United States: A cross-cultural comparison in New Zealand social studies: Past, present and future, edited by Roger Openshaw. Palmerston North: Dunmore Press.

Thevenet, P. C. 1994. The beginnings of a standardized social studies curriculum in the elementary schools. Ed.D. diss., Teachers" College, Columbia University, New York.

Trethewey, A. R. 1968. The rise and fall of history in the Victorian state primary school: A study of a response to changing social purposes. Australian Journal of Education 12: 265-75.

Whelan, M. 1991. James Harvey Robinson, the new history, and the 1916 social studies report. The History Teacher 24(2): $191-202$.

1994. Old masters: Albert Bushnell Hart. Paper presented at the 74th Annual Conference of the National Council for Social Studies. Phoenix.

Yesterday.Today.Tomorrow.

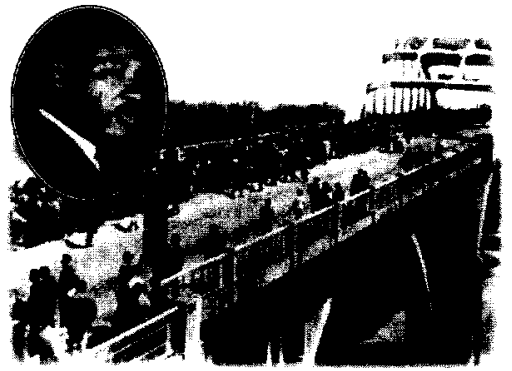

Famous 6 Historic Trees Bring History Alive!

Yesterday... On Matih 7, 1965 Martin Luther King, Jr. and his tollowers gathered heneath sycumore and live oak trees outside the Brown Chapel AME in Selma, Alabama

Today... The seeds from the original Martin Luther King, Jr. Sycamore and Live Oak trees have heen hand-picked and grown into small Airect-offspring trees.

Tomorrow... You can own and plant a historic tree and help AMERICAN FORESTS ontinue vUT work to presce trees and forest. far into the twenty-first century.

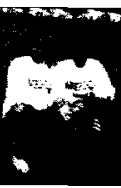

Call 1-904-765-0727 for your complimentary Famous \& Historic Trees booklet ar urite to AMERICAN FORESTS Famous of Historic Trees 8555 Plummer Ruad

Jacksonville, Fornda 32219

EMail: uww amtororg

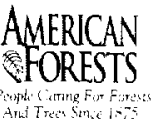

